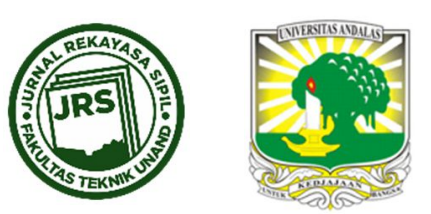

\title{
APLIKASI TEKNOLOGI REMOTE SENSING TERHADAP SEBARAN JARINGAN JALAN DI KOTA PALEMBANG
}

\author{
AKHMAD MIRZA ${ }^{1}$, ANDI HERIUS ${ }^{1}$, ARFAN HASAN $^{1}$, INDRAYANI $^{1^{*}}$ \\ ${ }^{1}$ Civil Engineering Department, State Polytechnic of Sriwijaya (mirzatin@gmail.com) \\ *Corresponding author: $ه$ iin_indrayani@polsri.ac.id
}

Naskah diterima : 26 Maret 2019. Disetujui: 12 November 2019

\begin{abstract}
ABSTRAK
Pendataan jaringan jalan di Kota Palembang diperlukan untuk mendapatkan panjang jaringan jalan yang ada di Kota Palembang, khususnya panjang jaringan jalan pada setiap kecamatan yang ada di kota Palembang. Hal ini dilakukan untuk mendukung pemerintah kota dalam pengambilan keputusan terhadap pembangunan infrastruktur jalan di kota Palembang. Pengambilan keputusan dalam menentukan pembangunan infrastruktur jalan dapat dilakukan dengan membandingkan indeks aksesibilitas wilayah pada setiap kecamatan yang ada. Nilai indeks aksesibilitas dihitung dengan membandingkan panjang jalan terhadap luas wilayah, semakin tinggi indeks aksesibilitas maka panjang ruas jalan semakin tinggi dan demikian pula sebaliknya. Penelitian ini dilakukan menggunakan teknologi remote sensing dengan memanfaatkan citra Landsat 8 yang diunduh dari USGS Landsat 8 Product (http://landsat.usgs.gov). Selanjutnuya dilakukan pengolahan terhadap citra sehingga dapat digunakan dalam menginterpretasi keberadaan jaringan jalan yang ada di kota Palembang dan membaginya per kecamatan. Dengan menggunakan teknologi remote sensing ini pendataan sebaran jaringan jalan dapat lebih efektif dan efisien. Hasil analisa menunjukan bahwa indeks aksesibilitas jalan tertinggi adalah pada Kecamatan Ilir Barat I yaitu sebesar 14,11, sedangkan terendah pada Kecamatan Gandus, yaitu sebesar 1,88. Dari rata-rata nilai indeks aksesibilitas jalan yang diperoleh maka keberadaan jaringan jalan di kota Palembang masuk dalam katagori tinggi yaitu sebesar 5,73.
\end{abstract}

Kata kunci : Teknologi; Remote Sensing; Sebaran; Jaringan; Jalan

\section{LATAR BELAKANG}

Teknologi remote sensing atau dikenal dengan istilah teknologi penginderaan jauh, dewasa ini mengalami perkembangan yang sangat signifikan, diantaranya perkembangan teknologi pengambilan data maupun penggunaan perangkat lunak komputer dalam pengolahan datanya (Campbell \& Wynne, 2011; A. S. Putra et al., 2016). Beberapa penelitian-penelitian telah dilakukan berkaitan dengan keruangan menggunakan metode penginderaan jauh diantaranya yang telah dilakukan oleh Putra dan Fauzy (2015) yang menganalisis pemetaan potensi desa wisata dengan menggunakan teknologi penginderaan jauh; begitu pula 
penelitian-penelitian yang dilakukan Indrayani, Buchari, Putranto, dan Saleh (2017); Gandhi, Parthiban, Thummalu, dan Christy (2015); Wibowo, Sholichin, Rispiningtati, dan Asmaranto (2013) yang mengidentifikasi tutupan lahan menggunakan teknologi penginderaan jauh, dari hasil yang didapatkan bahwa tutupan lahan dapat diklasifikasikan sesuai dengan nilai spektral yang dipancarkan. Indica, Ulqodry, dan Hendri (2011) juga melakukan penelitian tentang perubahan luasan mangrove dengan menggunakan teknologi penginderaan jauh. Sedangkan penelitan terhadap jaringan jalan, baik terhadap jaringan jalan perkotaan maupun terhadap penanganan jalan juga telah dilakukan Antonius, Purnawan, dan Yosritzal (2017); Endri, Yossyafra, dan Gunawan (2014). Dari penelitianpenelitian sebelumnya yang telah menggunakan teknologi penginderaan jauh untuk mengidentifikasi berbagai objek yang ada dipermukaan bumi ini, sehingga keberadaan jaringan jalan tentunya juga dapat didata dengan menggunakan metode penginderaan jauh ini.

Keberadaan jalan sangat dibutuhkan dalam menunjang pertumbuhan perekonomian suatu wilayah, hal ini dikarenakan pergerakan barang dan jasa umumnya di Indonesia masih bergantung pada prasarana jalan yang (Munawar, 2007; Pemerintah Republik Indonesia, 2006). Pembangunan jalan yang tidak merata tentunya akan berpengaruh pada tingkat cepat atau lambatnya pertumbuhan perekonomian suatu daerah. Untuk perlu dilakukan pendataan terhadap sebaran jalan yang ada, sehingga dalam perencanaan pembangunan jalan perlu diperhatikan daerah-daerah yang masih memiliki indeks aksesibilitas wilayah yang rendah, dimana perbandingan antara keberadaan jalan dengan luas wilayah masih sangat rendah. Sehingga pembangunan jalan yang terus dilakukan tentunya harus memperhatikan indeks aksesibilitas wilayah, untuk memperoleh sebaran jaringan jalan yang merata pada setiap daerah.

Pengambilan keputusan dalam menentukan pembangunan infrastruktur jalan dapat dilakukan dengan membandingkan indeks aksesibilitas wilayah pada setiap kecamatan yang ada. Nilai indeks aksesibilitas dihitung dengan membandingkan luas wilayah terhadap panjang jalan, semakin tinggi indeks aksesibilitas maka panjang ruas jalan semakin tinggi dan demikian pula sebaliknya. Kota Palembang merupakan ibu kota Provinsi Sumatera Selatan yang memiliki 18 kecamatan dengan luas daerah 40,061 Ha (BPS Kota Palembang, 2018), untuk mendapatkan nilai indeks aksesibilitas pada setiap kecamatan maka perlu dilakukan identifikasi jaringan jalan yang ada pada setiap kecamatan yang ada di kota Palembang.

\section{METODOLOGI PENELITIAN}

\subsection{Lokasi Penelitian}

Kota Palembang merupakan ibu kota Provinsi Sumatera Selatan yang terletak antara $2^{\circ} 52^{\prime}$ $3^{\circ} 5^{\prime}$ Lintang Selatan dan $104^{\circ} 37^{\prime}-104^{\circ} 52^{\prime}$ Bujur Timur. Wilayah kajian penelitian dapat dilihat pada Gambar 1. 


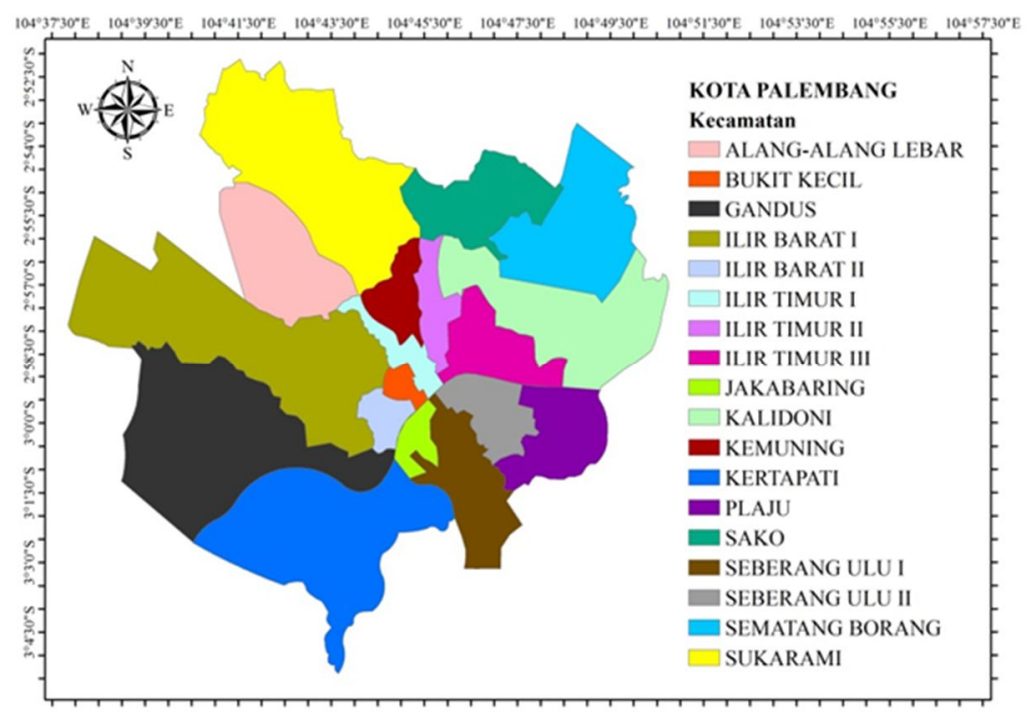

Gambar 1. Wilayah Kajian

Kota Palembang berbatasan langsung dengan Kabupaten Banyuasin pada bagian Utara, Timur dan Barat, sedangakan pada bagian Selatan berbatasan langsung dengan Kabupaten Muara Enim dan Kabupaten Ogan Ilir. Wilayah administratif kota Palembang terdiri dari 16 Kecamatan dan 107 Kelurahan dengan luas wilayah kurang lebih 40,061 Ha (BPS Kota Palembang, 2018).

\subsection{Alat dan Bahan}

Peralatan yang digunakan dalam penelitian ini meliputi perangkat komputer lengkap dan GPS. Sedangkan data citra yang akan digunakan dalam penelitian ini adalah citra satelit Landsat 8 yang diunduh dari United States Geological Survey (USGS, http://landsat.usgs.gov), yang melingkupi scene : path 124/ row 061.

\subsection{Tahapan Penelitian}

Penelitian ini terdiri dari beberapa tahapan seperti yang diuraikan pada diagram alir penelitian Gambar 2.

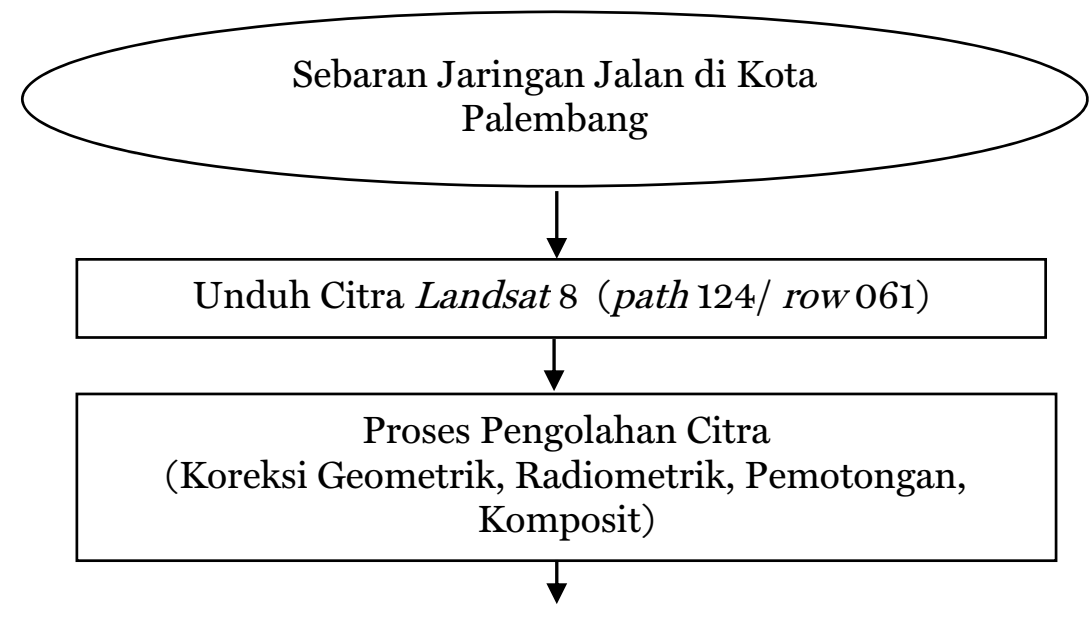




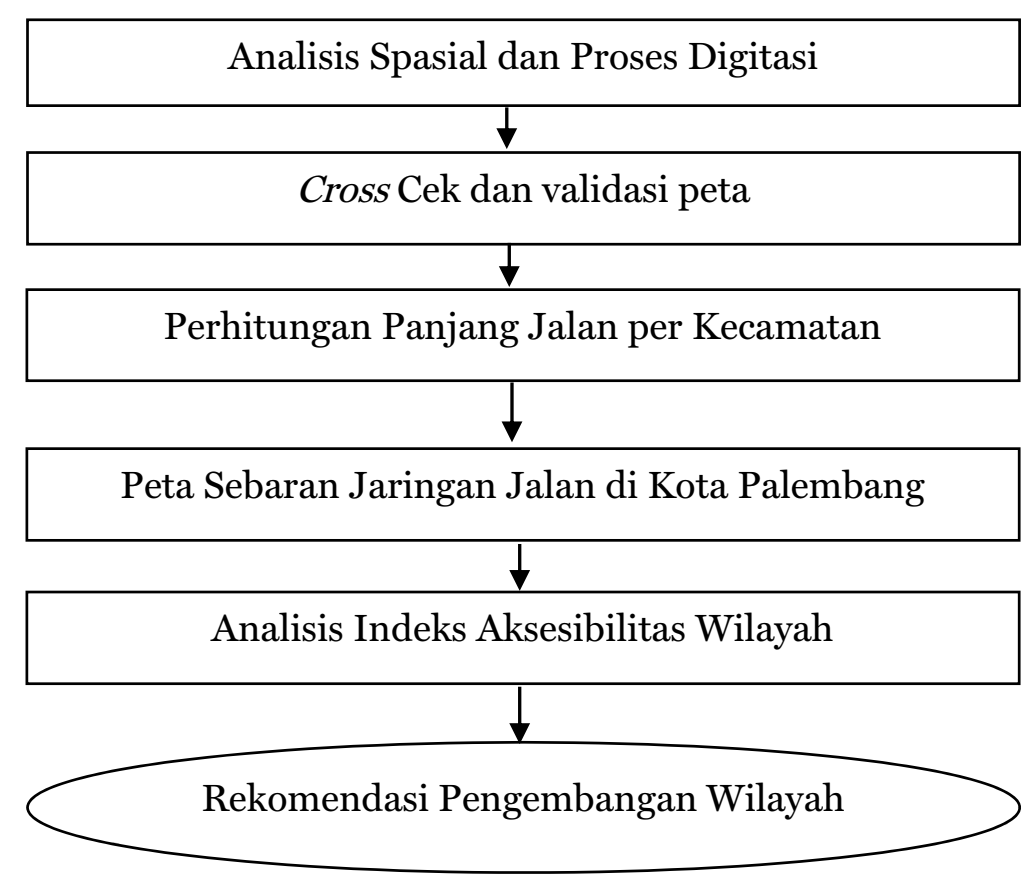

Gambar 2. Diagram Alir Penelitian

\subsection{Analisis Data}

Proses interpretasi dan digitasi jaringan jalan terhadap citra landsat 8, dilakukan dengan menggunakan program ArcGIS Online Map Viewer World Imagery. Validasi hasil interpretasi dilakukan dengan cara cross check hasil interpretasi jaringan jalan. Dari hasil digitasi terhadap jaringan jalan selanjutnya dihitung panjang jalan berdasarkan kecamatan yang ada, sehingga dapat dilakukan analisis terhadap indeks kondisi aksesibilitas jalan perkecamatan (Lapan, 2015; Purwadhi, 2001; USGS Landsat Mission, 2016). Analisis indeks aksesibillitas dihitung dengan menggunakan persamaan :

$$
\text { Nilai Indeks Aksesibilitas = panjang jalan } / \text { luas wilayah }\left(\mathrm{km} / \mathrm{km}^{2}\right)
$$

\section{HASIL DAN DISKUSI}

\subsection{Klasifikasi Jaringan Jalan Kota Palembang}

Interpretasi jaringan jalan di kota Palembang dilakukan melalui pengenalan kenampakan jaringan jalan yang ada pada citra landsat 8 dan ArcGIS Online Map Viewer, selanjutnya dilakukan proses digitasi jaringan jalan pada 18 kecamatan yang ada dikota Palembang. Klasifikasi jaringan jalan dibagi kedalam 4 kelas, yaitu jalan arteri, jalan kolektor, jalan lokal, dan jalan lingkungan. Digitasi jaringan jalan pada 18 kecamatan yang ada di kota Palembang dapat dilihat pada Gambar 3. 


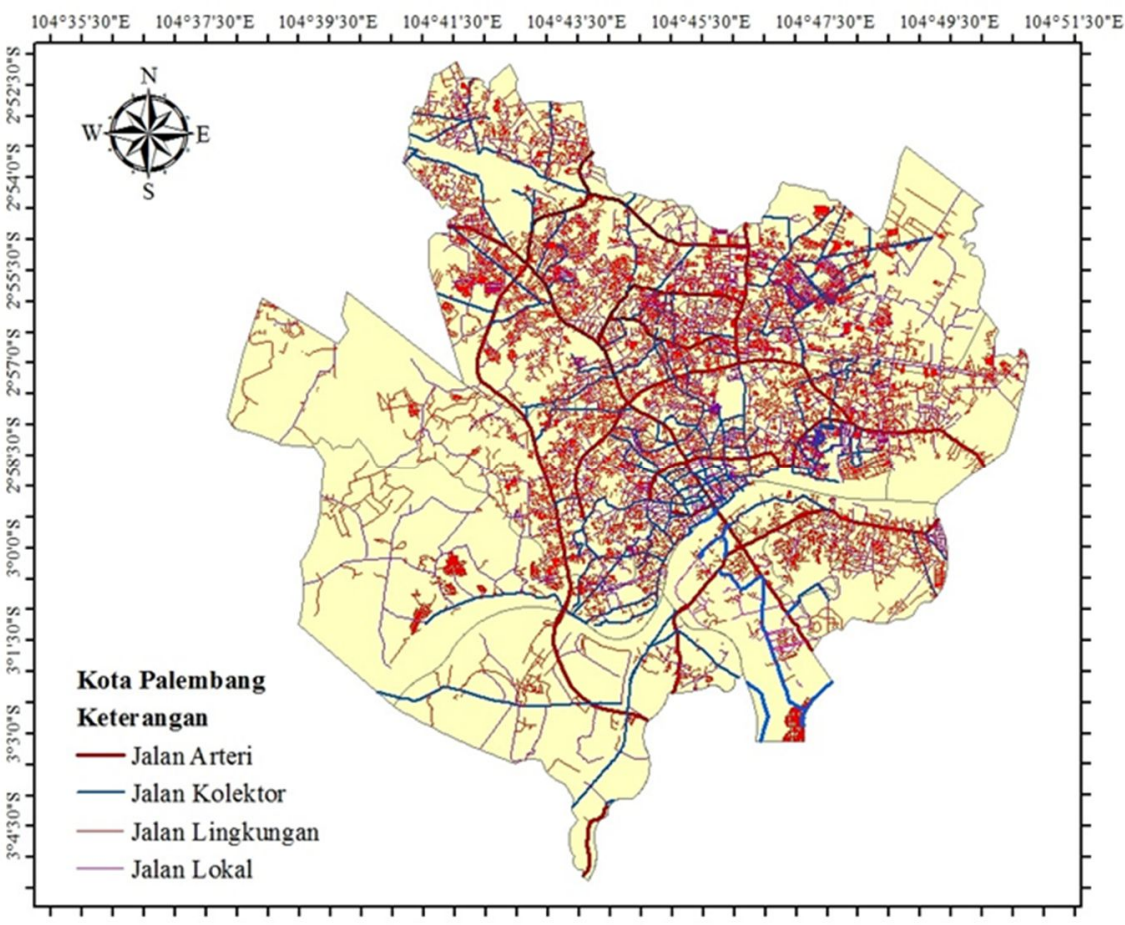

Gambar 3. Klasifikasi Jaringan Jalan Kota Palembang

\subsection{Validasi Peta Jaringan Jalan}

Akurasi dari hasil klasifikasi jaringan jalan diuji dengan menggunakan matrik kesalahan (confusion matrix), melalui cross check jaringan jalan hasil klasifikasi dengan kondisi eksisting jarigan jalan dilapangan. Lokasi cross check lapangan dapat dilihat pada gambar 4. Sedangkan matrik kesalahan pada klasifikasi jaringan jalan dapat dilihat pada Tabel 1.

Dari hasil cross check hasil klasifikas jalan bahwa tingkat akurasi hasil interpretasi adalah 95,07\%. Selanjutnya dilakukan analisa terhadap hasil interpretasi jalan per kecamatan sehingga didapatkan indeks aksesibilitas jalan pada tiap-tiap kecamatan. 


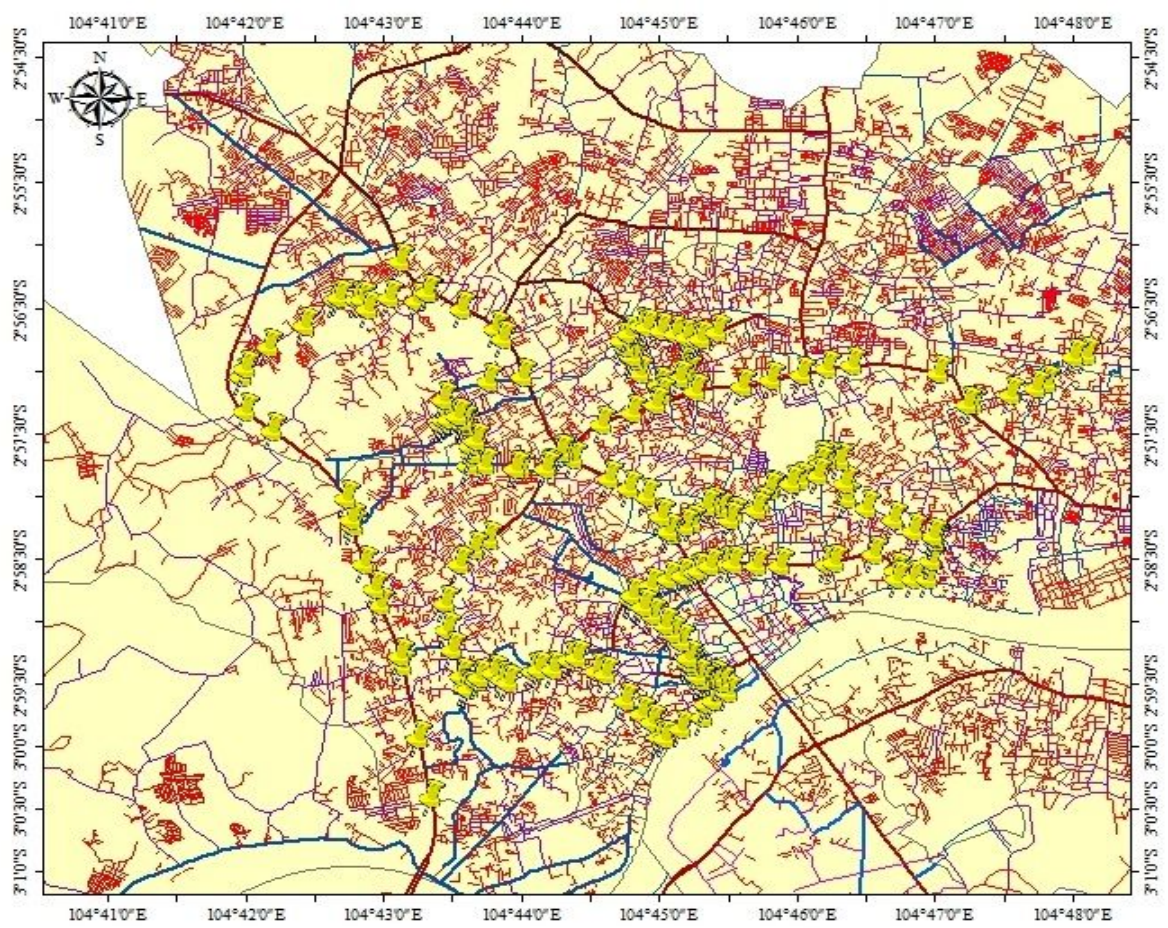

Gambar 4. Lokasi Cross Check Lapangan

Tabel 1. Matrik Kesalahan pada Klasifikasi Jaringan Jalan

\begin{tabular}{|c|c|c|c|c|c|c|c|}
\hline & & \multicolumn{4}{|c|}{ Data Acuan (Lapangan) } & \multirow[b]{2}{*}{$\begin{array}{l}\text { Total } \\
\text { Kolom }\end{array}$} & \multirow{2}{*}{$\begin{array}{l}\text { Akurasi } \\
\text { Pengguna } \\
\text { (User } \\
\text { Accuracy) }\end{array}$} \\
\hline & Uraian & $\begin{array}{l}\text { Jalan } \\
\text { Arteri }\end{array}$ & $\begin{array}{c}\text { Jalan } \\
\text { Kolektor }\end{array}$ & $\begin{array}{l}\text { Jalan } \\
\text { Lokal }\end{array}$ & $\begin{array}{c}\text { Jalan } \\
\text { Lingkungan }\end{array}$ & & \\
\hline \multirow{4}{*}{ 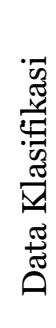 } & Jalan Arteri & 10 & 0 & 0 & 0 & 10 & 100,00 \\
\hline & Jalan Kolektor & 2 & 25 & 0 & 0 & 27 & 92,59 \\
\hline & Jalan Lokal & 0 & 0 & 40 & 3 & 43 & 93,02 \\
\hline & Jalan Lingkungan & 0 & 0 & 2 & 60 & 62 & 96,77 \\
\hline \multicolumn{2}{|c|}{ Total Baris } & 12 & 25 & 42 & 63 & 142 & \\
\hline \multicolumn{2}{|c|}{$\begin{array}{l}\text { Akurasi Produser } \\
\text { (Produser's Accuracy) }\end{array}$} & 83,33 & 100,00 & 95,24 & 95,24 & & 95,07 \\
\hline
\end{tabular}

\subsection{Validasi Peta Jaringan Jalan}

Pengukuran panjang jalan dilakukan terhadap masing-masing kriteria jalan (jalan arteri, jalan kolektor, jalan lokal, dan jalan lingkungan). Tabel 2 menunjukkan hasil pengukuran panjang jalan. 
Tabel 2. Panjang Jaringan Jalan per Kecamatan di Kota Palembang

\begin{tabular}{|c|c|c|c|c|c|c|}
\hline \multirow[b]{2}{*}{ No } & \multirow[b]{2}{*}{ Kecamatan } & \multicolumn{4}{|c|}{ Panjang Jalan (KM) } & \multirow{2}{*}{$\begin{array}{l}\text { Total per } \\
\text { Kecamatan } \\
(\mathrm{KM})\end{array}$} \\
\hline & & $\begin{array}{l}\text { Jalan } \\
\text { Arteri }\end{array}$ & $\begin{array}{c}\text { Jalan } \\
\text { Kolektor }\end{array}$ & $\begin{array}{l}\text { Jalan } \\
\text { Lokal }\end{array}$ & $\begin{array}{c}\text { Jalan } \\
\text { Lingkungan }\end{array}$ & \\
\hline 1 & Alang-Alang Lebar & 8,095 & 12,526 & 38,073 & 119,839 & 178,533 \\
\hline 2 & Sukarame & 18,248 & 36,036 & 107,615 & 246,238 & 408,136 \\
\hline 3 & Sematang Borang & 0 & 7,340 & 48,971 & 100,681 & 156,992 \\
\hline 4 & Sako & 5,556 & 17,363 & 46,630 & 98,552 & 168,101 \\
\hline 5 & Kalidoni & 12,581 & 16,707 & 69,798 & 147,949 & 247,034 \\
\hline 6 & Ilir Timur I & 5,923 & 11,538 & 10,357 & 24,902 & 52,721 \\
\hline 7 & Ilir Timur II & 2,899 & 12,345 & 24,759 & 53,828 & 93,831 \\
\hline 8 & Ilir Timur III & 3,150 & 13,825 & 23,150 & 43,615 & 83,740 \\
\hline 9 & Ilir Barat I & 8,668 & 17,478 & 58,731 & 194,035 & 278,913 \\
\hline 10 & Ilir Barat II & 0 & 7,479 & 11,823 & 28,397 & 47,699 \\
\hline 11 & Kemuning & 4,814 & 8,254 & 21,785 & 49,143 & 83,997 \\
\hline 12 & Bukit Kecil & 1,917 & 6,407 & 7,559 & 7,297 & 23,180 \\
\hline 13 & Gandus & 1,508 & 13,533 & 31,585 & 82,366 & 128,992 \\
\hline 14 & Seberang Ulu I & 3,904 & 13,277 & 16,837 & 34,348 & 68,366 \\
\hline 15 & Seberang Ulu II & 2,140 & 6,030 & 10,257 & 51,094 & 69,523 \\
\hline 16 & Jakabaring & 5,312 & 6,214 & 4,356 & 11,859 & 27,741 \\
\hline 17 & Kertapati & 10,305 & 17,753 & 27,250 & 41,160 & 96,469 \\
\hline 18 & Plaju & 3,502 & 3,775 & 26,313 & 54,340 & 87,929 \\
\hline \multicolumn{2}{|c|}{ Total per klasifikasi (KM) } & 98,522 & 221,668 & 585,850 & $1.389,644$ & $2.295,683$ \\
\hline
\end{tabular}

\subsection{Analisis Indeks Aksesibilitas Jaringan Jalan}

Analisa indeks aksesibilitas dihitung berdasarkan perbandingan luas wilayah dengan panjang jalan. Luas wilayah pada masing-masing kecamatan dapat dilihat pada Tabel 3.

Tabel 3. Luas Wilayah Kecamatan di Kota Palembang

\begin{tabular}{clrr}
\hline No & Kecamatan & Luas $\left(\mathbf{k m}^{2}\right)$ & \multicolumn{2}{c}{ Panjang Jalan $(\mathbf{k m})$} \\
\hline 1 & Alang-Alang Lebar & 34,581 & 178,533 \\
2 & Sukarame & 51,459 & 408,136 \\
3 & Sematang Borang & 36,980 & 156,992 \\
4 & Sako & 18,040 & 168,101 \\
5 & Kalidoni & 27,920 & 247,034 \\
6 & Ilir Timur I & 6,500 & 52,721 \\
7 & Ilir Timur II & 13,858 & 93,831 \\
8 & Ilir Timur III & 11,722 & 83,740 \\
9 & Ilir Barat I & 19,770 & 278,913 \\
10 & Ilir Barat II & 6,220 & 47,699 \\
11 & Kemuning & 9,000 & 83,997 \\
12 & Bukit Kecil & 9,920 & 23,180 \\
13 & Gandus & 68,780 & 128,992 \\
14 & Seberang Ulu I & 10,719 & 68,366 \\
15 & Seberang Ulu II & 10,690 & 69,523 \\
16 & Jakabaring & 6,721 & 27,741 \\
17 & Kertapati & 42,560 & 96,469 \\
18 & Plaju & 15,170 & 87,929 \\
\hline Total & & 400,61 & $2.295,683$ \\
\hline
\end{tabular}


Hasil perhitungan indeks aksesibilitas jaringan jalan dapat dilihat pada Tabel 4.

Tabel 4. Hasil Perhitungan Nilai Indeks Aksesibilitas Jaringan Jalan

\begin{tabular}{clll}
\hline No & Kecamatan & Indeks Aksesibilitas per km & Katagori \\
\hline 1 & Alang-Alang Lebar & 5,16 & Sangat Tinggi \\
2 & Sukarame & 7,93 & Sangat Tinggi \\
3 & Sematang Borang & 4,24 & Tinggi \\
4 & Sako & 9,32 & Sangat Tinggi \\
5 & Kalidoni & 8,85 & Sangat Tinggi \\
6 & Ilir Timur I & 8,11 & Sangat Tinggi \\
7 & Ilir Timur II & 6,77 & Sangat Tinggi \\
8 & Ilir Timur III & 7,14 & Sangat Tinggi \\
9 & Ilir Barat I & 14,11 & Sangat Tinggi \\
10 & Ilir Barat II & 7,67 & Sangat Tinggi \\
11 & Kemuning & 9,33 & Sangat Tinggi \\
12 & Bukit Kecil & 2,34 & Tinggi \\
13 & Gandus & 1,88 & Tinggi \\
14 & Seberang Ulu I & 6,37 & Sangat Tinggi \\
15 & Seberang Ulu II & 6,50 & Sangat Tinggi \\
16 & Jakabaring & 4,12 & Tinggi \\
17 & Kertapati & 2,27 & Tinggi \\
18 & Plaju & 5,80 & Sangat Tinggi \\
\hline Total & & 5,73 & Sangat Tinggi \\
\hline
\end{tabular}

Dari Tabel 4., dapat dilihat bahwa total indeks aksesibilitas jaringan jalan yang ada dikota Palembang menunjukkan bahwa jaringan jalan dikota Palembang masuk dalam katagori "sangat tinggi", ini berarti pemerintah kota Palembang telah mengembangkan jaringan jalan dengan baik untuk mendukung pertumbuhan perekonomian kota Palembang.

Kecamatan yang memiliki peringkat indeks aksesibilitas jaringan jalan tertinggi adalah pada Kecamatan Ilir Barat I, walaupun Kecamatan Sukarame memiliki panjang jalan tertinggi namun indeks askesibilitas jaringan jalan berada pada peringkat ke 6 , hal ini dikarenakan Kecamatan Sukarame memiliki luas wilayah terbesar kedua setelah Gandus. Kecamatan Gandus merupakan wilayah kecamatan terluas namun memiliki indeks aksesibilitas jaringan jalan terkecil sehingga Kecamatan Gandus menduduki peringkat ke 18 dari keseluruhan kecamatan yang ada di kota Palembang.

Dari hasil nilai indeks aksesibilitas jalan ini, maka dapat menjadi pedoman bagi pemerintah dalam mengembangkan jaringan jalan yang ada di Kota Palembang, yaitu dengan mengutamakan kecamatan yang memiliki indeks aksesibilitas jalan terendah, disamping pertimbangan lain yang dibutuhkan.

\section{KESIMPULAN}

Total panjang jalan di Kota Palembang yang didapatkan dari hasil interpretasi citra adalah $2.295,683 \mathrm{~km}$, yang terdiri dari 98,52 km jalan arteri; $221,67 \mathrm{~km}$ jalan kolektor; $585,85 \mathrm{~km}$ jalan lokal; dan 1389,64 km jalan lingkungan. Sedangkan panjang jaringan jalan tertinggi adalah pada Kecamatan Sukarame, yaitu 408,136 km, dan terkecil pada Kecamatan Bukit Kecil, sebesar 23,18 km. Nilai indeks aksesibilitas jaringan jalan terbesar adalah pada Kecamatan Ilir Barat I, yaitu 14,11, sedangkan yang terkecil pada Kecamatan Gandus, yaitu sebesar 1,88. Rata-rata indeks aksesibilitas jaringan jalan kota Palembang adalah sebesar 5,73, nilai ini masuk ke dalam kategori sangat tinggi tinggi. 


\section{DAFTAR PUSTAKA}

Antonius, T., Purnawan, P., \& Yosritzal, Y. (2017). Studi Perbandingan Prioritas Penanganan Jalan Provinsi di Sumatera Barat. Jurnal Rekayasa Sipil (JRS-Unand), 13(1), 43-54.

Badan Pusat Statistik. (2018). Kota Palembang Dalam Angka 2018. Palembang.

Campbell, J. B., \& Wynne, R. H. (2011). Introduction to remote sensing (Fifth Edition ed.). London: Guilford Press.

Endri, E., Yossyafra, Y., \& Gunawan, H. (2014). Local Area Traffict Management Pada Jalan Perkotaan Kawasan Pendidikan dan Pemukiman (Studi Kasus Jalan Gajah Mada Kota Padang) Jurnal Rekayasa Sipil (JRS-Unand), 1O(1), 43-56.

Gandhi, G. M., Parthiban, S., Thummalu, N., \& Christy, A. (2015). Ndvi: Vegetation change detection using remote sensing and gis-A case study of Vellore District. Procedia Computer Science, 57, 1199-1210.

Indica, M., Ulqodry, T. Z., \& Hendri, M. (2011). Perubahan Luasan Mangrove dengan Menggunakan Teknik Penginderaan Jauh Di Taman Nasional Sembilang Kabupaten Banyuasin Provinsi Sumatera Selatan. Maspari Journal: Marine Science Research, 2(1), 77-81.

Indrayani, Buchari, E., Putranto, D. D., \& Saleh, E. (2017). Analysis of land use in the Banyuasin district using the image Landsat 8 by NDVI method. Paper presented at the AIP Conference Proceedings.

Lapan. (2015). Pedoman Pemanfaatan Data Landsat-8 untuk Deteksi Daerah Tergenang Banjir (Inundated Area): Pusat Pemanfaatan Penginderaan Jauh, Lembaga Penerbangan dan Antariksa Nasional.

Munawar, A. (2007). Pengembangan transportasi yang berkelanjutan. Retrieved from http://repository.ugm.ac.id/digitasi/index.php?module=cari_hasil_full\&idbuku=1098

Pemerintah Republik Indonesia. (2006). Peraturan Pemerintah nomor 34 tahun 2006 tentang jalan. Jakarta (ID): Sekretariat Negara.

Purwadhi, S. H. (2001). Interpretasi citra digital. Jakarta: Grasindo.

Putra, A. S., \& Fauzy, A. (2015). Pemetaan Lokasi Potensi Desa Wisata di Kabupaten Sleman Tahun 2015. Asian Journal of Innovation and Entrepreneurship, 4(2), 123-129.

Putra, A. S., Maulana, E., Rahmadana, A. D. W., Wulan, T. R., Mahendra., I. W. W. Y., \& Putra, M. D. (2016). Accuration Test of UAV's Aerial Photo in Densely Populated Areas (Case Study: Sayidan, Special Province of Yogyakarta). Published on Sinas Indraja, LAPAN.

USGS Landsat Mission. (2016). Using the USGS Landsat8 Product. US Department of the InteriorUS Geological Survey-NASA.

Wibowo, L. A., Sholichin, M., Rispiningtati, R., \& Asmaranto, R. (2013). Penggunaan Citra Aster Dalam Identifikasi Peruntukan Lahan Pada Sub Das Lesti (Kabupaten Malang). Jurnal Teknik Pengairan, 4(1), 39-46. 